\title{
Spatio-temporal characteristics of rural settlements and land use in the Bohai Rim of China
}

\author{
YANG Ren ${ }^{1},{ }^{*}$ LIU Yansui ${ }^{2,3}$, LONG Hualou², QIAO Luyin² \\ 1. School of Geography and Planning, Sun Yat-sen University, Guangzhou 510275, China; \\ 2. Institute of Geographic Sciences and Natural Resources Research, CAS, Beijing 100101, China; \\ 3. School of Resource Science, Beijing Normal University, Beijing 100875, China
}

\begin{abstract}
Based on multiple remote-sensing image interpretation and classification, and economic and social data, this study focused on rural settlement and land use change amidst rapid urbanization. Rural settlements, spatial and temporal patterns of land use and influencing factors in the Bohai Rim were explored within $5 \times 5 \mathrm{~km}$ grid cells, as per GIS spatial analysis and geostatistical analysis. Results show that the spatial distribution of rural settlements in the Bohai Rim is remarkably varied. The number of rural settlement sites in a $5 \times 5 \mathrm{~km}$ grid cell exceeding 5.0 are distributed in a six-area pattern in the Bohai Rim; rural settlement dispersion is particularly high in agricultural regions in south Hebei and southwest Shandong, suggesting rural settlement density keeps increasing from northeast to southwest, characterized by high density and dispersed spatial distribution in traditional agricultural regions. Furthermore, rural settlements show dramatic spatial differences in terms of distribution and dynamic change degrees in the Bohai Rim. In terms of spatial distribution, rural residential land is always extensive in plains, with a high density of rural settlements, on the North China Plain in particular, and rural residential land in the south of Shandong province is also extensive, with most rural settlement land use areas in the $5 \times 5 \mathrm{~km}$ grid cells exceeding $3 \mathrm{~km}^{2}$. However, traditional agricultural regions have underdeveloped economies, industrialization and tertiary industries, characterized by low urbanization rates, with farmers not feeling assimilated in rural or urban areas. In terms of the temporal sequence, urban expansion rapidly promotes the transformation of rural residential lands in rural-urban transitional belts of provincial capital or prefecture-level city into urban lands, and in traditional rural areas, residential lands are growing. The natural environment, transportation conditions, economic development and farmers' incomes all have effects on type of land use change and pattern of rural settlements. It is a core objective for future rural development to reconstruct a rational spatial pattern of villages or towns and well-organized village-town systems, build central villages, key towns or central towns, optimize or reconstruct production, living and eco-space of rural areas. It is of significance for rural geographical research to further interpret and explore spatial reconstruction theory.
\end{abstract}

Keywords: rural residential lands; influence mechanism; rural geography; Bohai Rim; China

Received: 2014-07-05 Accepted: 2014-12-30

Foundation: National Natural Science Foundation of China, No. 41401190; No.41130748; No.41101165

Author: Yang Ren (1984-), PhD and Lecturer, specialized in rural reconstruction, rural-urban transformation and land use optimal allocation. E-mail: yangren0514@163.com

*Corresponding author: Liu Yansui (1965-), Professor, specialized in land science and agriculture and rural development. E-mail: liuys@igsnrr.ac.cn 


\section{Introduction}

A village is a clustered community for societies that practice agriculture and a settlement refers to the sites where people live and work (Jin, 1988; Guo et al., 2012; Zhou et al., 2013). A rural settlement is a type of rural locality where rural residents live and engage in production, resulting from interactions of local residents with natural, economic, social and cultural environments (Long et al., 2012; Shan et al., 2012; Liu et al., 2014). It is fundamental to rural geographical research, as well as an important part of research on territorial systems of human-environment interactions (Liu et al., 2013b), with ongoing studies on the structure, pattern, and landscape evolution of rural settlements (Woods, 2007; Giuseppina, 2012; Yang et al., 2012; Liu et al., 2013a; Guo et al., 2013).

A rural settlement, with territorial functions of traditional agricultural production and processing, is closely related to agricultural lands and rural populations in terms of settlement pattern and scale, restricted by agricultural science and technology, and farming radius has direct effects on rural settlement pattern in agricultural society (Yin and Chen, 1995; Woods, 2005; Han and Cai, 2011; Zhou et al., 2013; Liu et al., 2010; 2014). With rural-urban development transformation, the allocation of rural factors has undergone dramatic changes (Bai et al., 2014). For example, the rate of non-agriculturalization and scale of agricultural production factors, represented by labor force and cultivated land, continue growing, accompanied by the transition of rural settlements and land use (Liu et al., 2009; Liu and Yang, 2012; Long, 2014). Because of rapid urbanization and the loosening of the urban-rural dual system, the flow of factors of production is reinforced between rural and urban areas (Long et al., 2010). For instance, an increasing number of factors of production in rural areas go through non-agriculturalization and the rural population is moving to urban areas (Liu and Yang, 2012; Yang et al., 2012). Consequently, empty-nest families and rural hollowing issues become commonplace in the countryside, resulting in tremendous changes in local economic and social structures as well as land use patterns. In practice, emphasis is given to urban research, and research on rural settlements and land use develops modestly (Mathera et al., 2006; Xi et al., 2011). Recently, driven by new rural construction and "beautiful countryside" construction, many researchers have turned their attention to rural settlement patterns (Tian et al., 2012), type and function, rural hollowing issues, rural settlement ecology, spatial characteristics and evolution of rural settlements, problems of rural settlement development, and so on (Long et al., 2009; He et al., 2012), but they are still restricted to county or village level, so that a deep analysis is never made of the temporal and spatial characteristics and distribution of rural settlements and residential lands (Guo et al., 2012; Long, 2014).

In the current research, using remote sensing images of rural settlements extracted, changes in spatial patterning and area of rural settlements were analyzed in the Bohai Rim over the last 20 years. Grid cells of $5 \times 5 \mathrm{~km}$ were used to explore the spatial and temporal evolution, distribution of rural settlements and influencing factors, as well as the economic and social driving mechanisms of land use changes at county level. Results will provide data to enable improvements in the manner of Chinese regional rural settlements at different development levels and the evolutionary trend of rural settlements and land use in the process of Chinese industrialization and urbanization, providing basic research for the reconstruction of rural settlements. At the same time, conclusions will be drawn from the perspective of 
theory, system and practice, in order to provide references for the selection of regions suitable for new-type urban-rural land use, new rural construction and the resolution of hollowing issues.

\section{Materials and methods}

\subsection{Study area}

We selected China's Bohai Rim (536,000 $\mathrm{km}^{2}$ ) as the study area. This region consists of Beijing, Tianjin, Hebei Province, Liaoning Province and Shandong Province (Figure 1), and has been experiencing rapid economic growth and urbanization development. Its per capita GDP increased from 5500 yuan/person in 1990 to 54505.8 yuan/person in 2010, while the urbanization level increased from $28.2 \%$ to $53.6 \%$ in the same period (Hebei Economic Yearbook, Beijing Statistical Yearbook and Tianjin Statistical Yearbook, 1991, 2001 and 2011). Recently, the Bohai Rim has come to be considered as China's "third engine", besides the Yangtze River Delta (which has Shanghai as the central city) and the Pearl River Delta (which has Guangzhou as the central city), promoting China's economy further in the 21st cen-

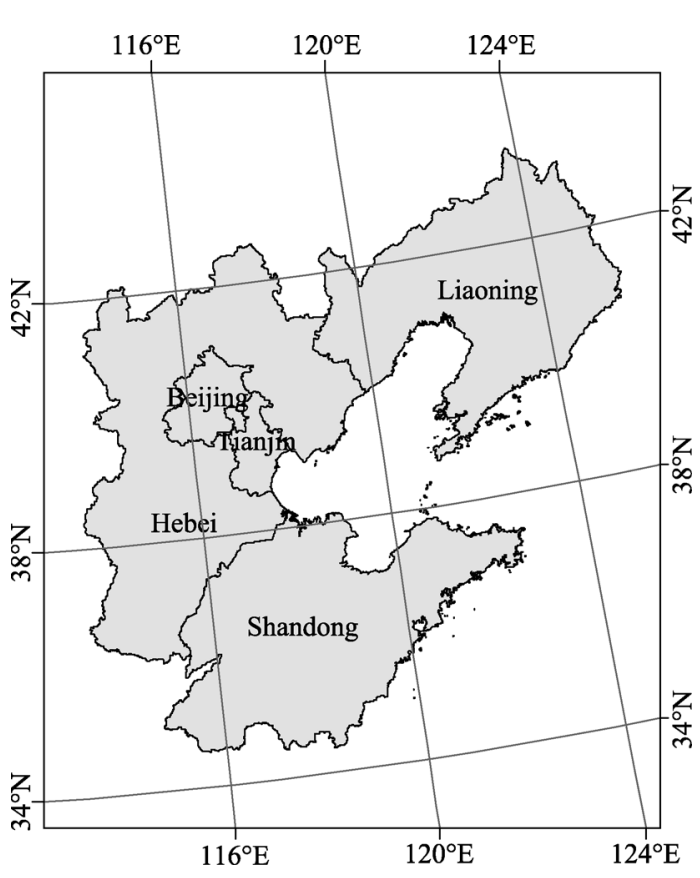

Figure 1 The location of the study area (Bohai Rim of China) tury.

\subsection{Data sources}

The research involved vector data of land use in 2010 in the Bohai Rim, which were obtained from TM remote sensing images by supervision, classification and revision, as well as data from the 1980s, 1995 and 2000, which were provided by the Institute of Remote Sensing Applications, CAS. Geographical data of spatial influencing factors were obtained from the China Electronic Map $(1: 250,000)$ in 2011, and meteorological data were taken from the Data Sharing Infrastructure of Earth System Science, Institute of Geographic Sciences and Natural Resources Research, CAS. Economic and social data used in the research were from the China Statistical Yearbook for Regional Economy, the China Statistical Yearbook for County or City Economy and Society, as well as provincial or municipal statistical yearbooks.

\subsection{Methodology}

(1) Statistics of rural settlement dispersion degree

Rural settlement evolution is a process of natural village development, and is hardly dis- 
tinguishable from administrative villages. Fortunately, GIS and RS make it possible to invert spatial and temporal processes of geographical objects. In this research, rural residential lands in the Bohai Rim in the 1980s, 1995, 2000, and 2010 were interpreted in a classified way and natural settlements in rural areas were extracted with a $5 \times 5 \mathrm{~km}$ grid cell, with statistics conducted on the dispersion degree of rural natural settlement in the Bohai Rim. Rural settlement dispersion degree defines the number of rural natural settlements in every grid cell, and the dynamic changes describe extension or extinction processes of rural settlements, spatially or temporally.

(2) Methods for detecting influencing factors of the spatial distribution of rural settlements

With consideration of comprehensive effects of natural conditions and economic location on rural settlements and spatial or temporal changes of land uses, a logistic stepwise regression was performed on rural settlement spatial distribution with influencing factors. The regression model was as follows:

$$
\log \left(\frac{P}{1-P}\right)=\beta_{0}+\beta_{1} x_{1}+\beta_{2} x_{2}+\cdots \beta_{n} x_{n}
$$

where $P$ is the probability of rural residential lands in every grid cell and $x_{n}$ represents influencing factors. Then, the regression results were examined with a ROC curve, with the optimal simulation scale explored.

(3) Geographical detector

The influence mechanism of rural settlement land use dynamic change degree was analyzed in counties with the geographical detector-based method. The geographical detector model is as follows (Wang et al., 2010; Yang et al., 2013):

$$
P_{D, U}=1-\frac{1}{n \sigma_{U}^{2}} \sum_{i=1}^{m} n_{D, i} \sigma_{U_{D, i}}^{2}
$$

where $P_{D, U}$ is detection force index of influencing factors on dynamic change degree of rural residential lands; $n_{d, i}$ is the number of samples of the secondary region; $n$ is the number of samples in the whole area and $m$ is the number in secondary regions; $\sigma_{U}^{2}$ represents variance of dynamic degrees of residential land changes and $\sigma_{U_{D, i}}^{2}$ represents the variance of secondary regions. Formally, $\sigma_{U_{D, i}}^{2} \neq 0$, and the range of $P_{D, U}$ is $[0,1]$, when $P_{D, U}=0$, it is suggested that dynamic degree of residential lands at county level is randomly distributed and the higher the $P_{D, U}$ value, the higher the influence of partitioning on the dynamic degree. In the research, a total of 13 indices were chosen, comprising: yield of a crop per unit area, total power of agricultural machinery, grain yield per labor force, irrigation rate, agricultural area per capita, labor force per unit of farmland, transportation, non-agricultural employment rate in rural areas, distance to downtown, terrain, primary industry, net income per capita and GDP per capita, with area partitioned, in order to make a quantitative detection of the relevant effects on changes of rural residential lands at county level.

\section{Results and analysis}

\subsection{Temporal and spatial evolution of rural residential sites}

From the distribution pattern, it can be seen that rural settlements in the Bohai Rim are remarkable in their spatial variation. The number of rural settlement sites in each $5 \times 5 \mathrm{~km}$ grid 
cell exceeding 5.0 are distributed across the six-area pattern, and rural villages in agricultural regions in the south of Hebei and southwest of Shandong are highly dispersed, suggesting rural settlement density keeps increasing from northeast to southwest, characterized by high density and dispersed spatial distribution in traditional agricultural regions (Figure 2), resulting from endless spatial extension from primitive settlements. With increasing population pressure, agricultural lands develop within effective distances to meet human demand, so that people are forced to seek space for living, resulting in a star-shaped distribution pattern. On the other hand, dispersion, disorder and hollowing are direct causes of extensive and low efficiency in land use in rural areas, where settlements are shaped based on farmers' independent choices in a long historical process, without scientific planning. In Shandong, for instance, most rural settlements are scattered, and the number of rural settlements in grid cells exceeds 10.0, indicating the issue of scattering and hollowing is common in rural residential lands. On the plateau of the Hebei and Changbai Mountains, rural settlements are also distributed in a dispersed manner, and the number in each grid cell is always below 5.0. It can be observed that rural settlements stretch extensively in plains or moderately sized or large cities.

As for dynamic changes, rural settlements in the Bohai Rim are been expanding, with much agricultural land being occupied, regional grain security is at risk. In the last 10 years, over $10 \%$ of the $5 \times 5 \mathrm{~km}$ grid units have become occupied by at least five rural settlements, laying pressure on agricultural production space (Figure 3). Moreover, the construction of rural residential sites has long continued without planning or guidance, leading to the
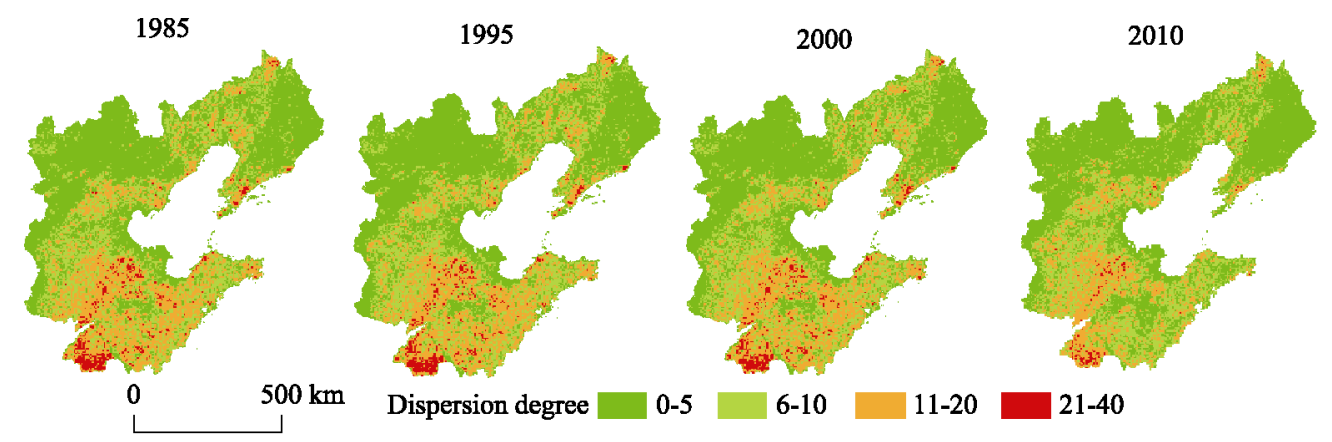

Figure 2 The spatial distribution of rural settlement site dispersion degree in $5 \times 5 \mathrm{~km}$ cells in 1985, 1995, 2000 and 2010 in the Bohai Rim of China

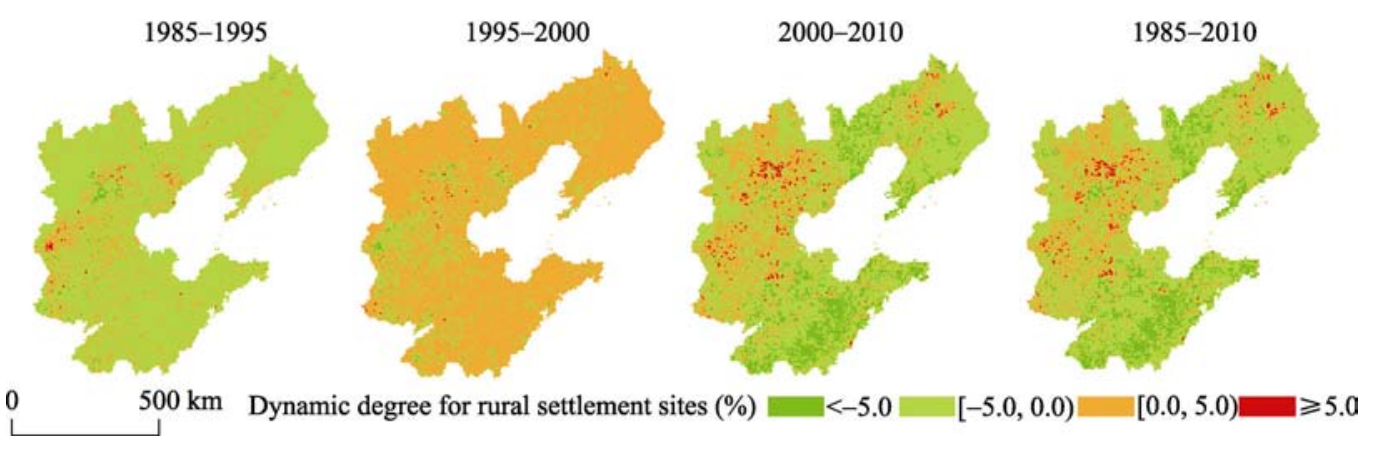

Figure 3 The spatial distribution of dynamic degree for rural settlement sites in a $5 \times 5 \mathrm{~km}$ grid cell from 1985 to 2010 in the Bohai Rim of China 
dispersed distribution of natural villages. For single rural residential sites, land use is dominated by extensive development and a disregard of original residential sites, causing expansion of rural residential lands. Besides, internal patterns of residential sites are disordered and construction intensity is not high. Therefore, there is a huge potential for redevelopment of rural residential, mining and industrial lands. With a long history, buildings of different ages or varied structures are scattered, without unified planning, and may have different orientations, disordered distributions, zigzag pathways, poor road quality, new village facades with old internal facilities, varied-graded raw materials and a shortage of infrastructure in public places. Currently, with the progression of non-agriculturalization, there is an urgent need to improve land use intensification in rural settlements.

\subsection{Significant spatial differences of land use distribution and dynamic degrees in rural residential sites in the Bohai Rim}

Rural settlements show dramatic spatial differences in terms of distribution and dynamic degrees in the Bohai Rim. With respect to distribution and scale, for example, rural residential land is always extensive on plains, with a high density of rural settlements, the North China Plain in particular and rural residential land in south Shandong also stretches extensively, with most residential sites in the $5 \times 5 \mathrm{~km}$ grid cell exceeding $3 \mathrm{~km}^{2}$. However, these traditional agricultural regions are underdeveloped in terms of economy, industrialization and tertiary industry, and are characterized by a low urbanization rate with farmers not feeling assimilated in rural or urban areas. Further, with a large population, traditional agricultural regions have witnessed housing expansion, and farmers find it hard to achieve self-fulfillment in towns or cities, worsened by the dual urban-rural security system. In terms of sequential variation, dynamic degrees are generally positive in rural residential areas. In the early stage, rural settlements in the rural-urban continuum are gradually integrated with the urban development and land use type is converted into urban land use. This is evident in rural areas surrounding provincial capitals and prefecture-level cities (Figures 4 and 5). Consequently, the urban-rural transition has changed land use types in rural settlements' neighboring cities, as well as landscape patterns. In this research, the number of grid cells containing rural settlements exceeding $3 \mathrm{~km}^{2}$ increased from 3174 (14.58\%) in 1985 to 3702 (17.00\%) in 2010. Between 1985 and 2010 the number of grid cells with positive dynamic degrees of rural settlement area increased to $57.38 \%$, mainly found in traditional agricultural regions, while over the same period the number of grid cells with negative dynamic degrees fell to $42.62 \%$, accounted for by large- and medium-sized city suburbs.

Demands on land for regional industrial development and urban and rural construction are highlighted by the optimized allocation of land use in the urban-rural transition. In the narrow sense, rural settlement land refers to the homestead of local residents. Theoretically, rapid urbanization would stimulate non-agriculturalization of the rural population, accompanied by a decline of rural land demands. In practice, however, the land is neither vacated nor returned to, and land area in rural settlements never reduces with non-agriculturalization. Since the 1980s, in particular, with rural land reform, labor forces in rural areas are liberated and most recessively-unemployed labor forces move to cities under the flexible hukou (household registration) system, so that both accumulated work time and income increase. 

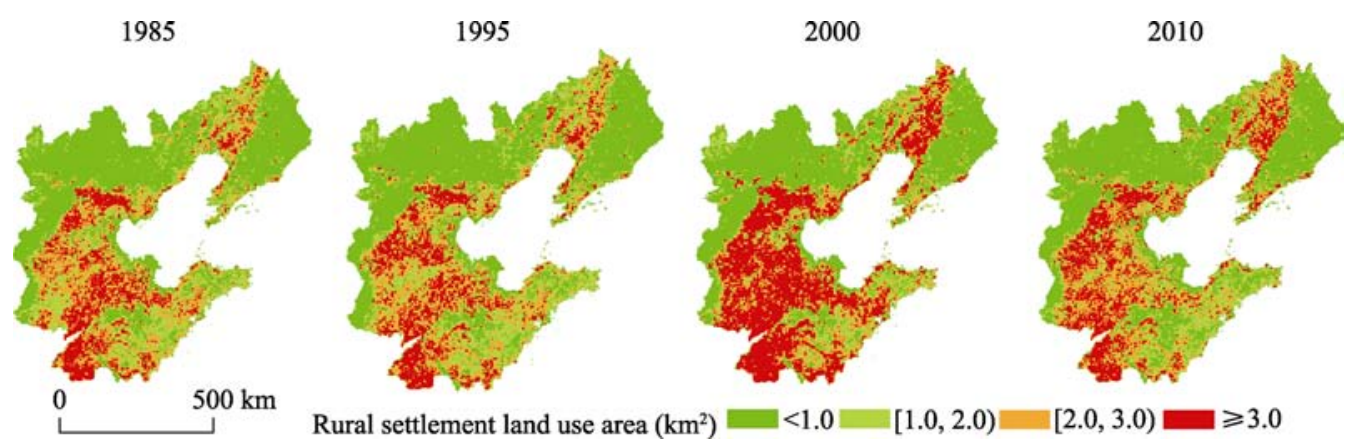

Figure 4 The spatial distribution of rural settlements land use area in a $5 \times 5 \mathrm{~km}$ grid cell in 1985, 1995, 2000 and 2010 in the Bohai Rim of China
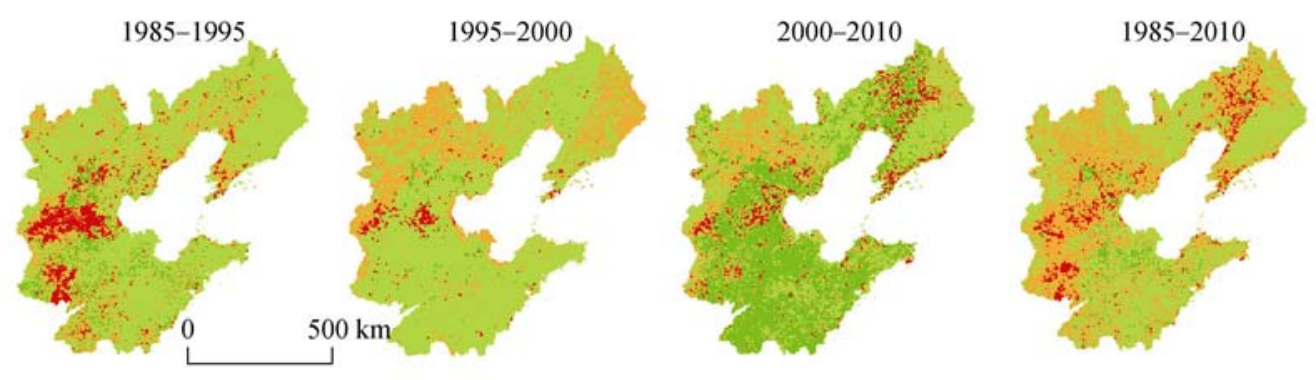

Dynamic degree for rural settlement land use area change (\%)

$<-0.5 \square[-5.0,0.0)$

$[0.0,5.0)$

$\geqslant 5.0$

Figure 5 The spatial distribution of dynamic degree for rural settlement land use area in a $5 \times 5 \mathrm{~km}$ cell from 1985 to 2010 in the Bohai Rim of China

Hence, more capital starts to flow back to rural areas, advancing house construction, although rural settlements are generally acknowledged to be disordered in their distribution, with land use often lacking planning, approval or management. With populations increasing and an urban-rural transition, the rural economy and farmers' living standards are improving, and the issue of illegal land use becomes much more serious in rural building construction, under the influence of the market economy and the traditional rural concept. Furthermore, isolated by the urban and rural social security system, it is harder for rural migrant workers to get a job or enjoy a good and prosperous life. Obviously it is just because of incomplete urbanization that leads to the continuous extension of rural settlements, causing the expansion of rural residential sites. We should recognize that rural residential sites are a crucial part of urban-rural construction, whose land scale and use is meaningful for social and economic evolution and for rural sustainable development. To resolve the issue of land use expansion in rural and urban areas and to make comprehensive improvements in construction on rural land, systematic urban and rural construction should be employed.

\subsection{Analysis of driving factors for land use variations in rural residential areas at county level}

Based on the statistics of rural residential areas in 327 counties in the Bohai Rim in 2000 and 2010, dynamic degrees of land use area can be computed. In the current research, a total of 13 indices were chosen: agricultural area per capita $\left(f_{1}\right)$, labor force per unit of cultivated 
land $\left(f_{2}\right)$, yield of a crop per unit area $\left(f_{3}\right)$, irrigation rate $\left(f_{4}\right)$, total power of agricultural machinery $\left(f_{5}\right)$, grain yield per labor force $\left(f_{6}\right)$, and GDP per capita $\left(f_{7}\right)$, primary industry $\left(f_{8}\right)$, net income per capita $\left(f_{9}\right)$, transportation $\left(f_{10}\right)$, distance to the center downtown $\left(f_{11}\right)$, terrain $\left(f_{12}\right)$, non-agricultural employment rate in rural areas $\left(f_{13}\right)$, with area partitioned, in order to make a quantitative detection on the relevant effects on changes of rural residential lands at county level. Using ArcGIS, every index is classified into high, middle and low grade zones as per natural clustering and classification, and the P-value of dynamic degrees of land use in rural areas can then be calculated, accordingly (Table 1).

Table 1 The geographic detected power of influencing factors for the rural residential land change

\begin{tabular}{ccccccccccccccc}
\hline Indices/ & $\mathrm{f}_{1}$ & $\mathrm{f}_{2}$ & $\mathrm{f}_{3}$ & $\mathrm{f}_{4}$ & $\mathrm{f}_{5}$ & $\mathrm{f}_{6}$ & $\mathrm{f}_{7}$ & $\mathrm{f}_{8}$ & $\mathrm{f}_{9}$ & $\mathrm{f}_{10}$ & $\mathrm{f}_{11}$ & $\mathrm{f}_{12}$ & $\mathrm{f}_{13}$ \\
\hline $\begin{array}{c}\text { Threshold } \\
\text { value }\end{array}$ & $\begin{array}{c}\left(\mathrm{hm}^{2} /\right. \\
\mathrm{per})\end{array}$ & $\begin{array}{c}(\mathrm{per} / \\
\left.\mathrm{hm}^{2}\right)\end{array}$ & $\begin{array}{c}\left(10^{3} \mathrm{~kg} /\right. \\
\left.\mathrm{hm}^{2}\right)\end{array}$ & $\begin{array}{c}(\%) \\
(\mathrm{kw} /\end{array}$ & $\begin{array}{c}\left(10^{3} \mathrm{~kg} /\right. \\
\left.\mathrm{hm}^{2}\right)\end{array}$ & $\begin{array}{c}\left(10^{3}\right. \\
\mathrm{per})\end{array}$ & $\begin{array}{c}\text { yuan }) \\
(\%)\end{array}$ & $\begin{array}{c}\left(10^{3}\right. \\
\text { yuan })\end{array}$ & $(\mathrm{km})$ & $(\mathrm{km})$ & $(\mathrm{m})$ & $(\%)$ \\
First zone & $<0.1$ & $<20$ & $<4.5$ & $<40$ & $<1.0$ & $<2.0$ & $<15$ & $<15$ & $<4.5$ & $<15$ & $<90$ & $<500$ & $<-10$ \\
Second zone & $0.1-0.2$ & $20-30$ & $4.5-8.0$ & $40-75$ & $1.0-1.5$ & $2.0-3.0$ & $15-30$ & $15-30$ & $4.5-7.5$ & $15-30$ & $90-150$ & $500-100$ & -10 to -5 \\
Third zone & $>0.2$ & $>30$ & $>8.0$ & $>75$ & $>1.5$ & $>3.0$ & $>30$ & $>30$ & $>7.5$ & $>30$ & $>150$ & $>1000$ & $>-5$ \\
P-value & 0.42 & 0.35 & 0.32 & 0.21 & 0.33 & 0.38 & 0.82 & 0.27 & 0.81 & 0.58 & 0.72 & 0.66 & 0.42 \\
\hline
\end{tabular}

At first, rural economic development and non-agricultural employment considerably affects land use of rural residential lands. The P-values of GDP per capita, net income per capita and non-agricultural employment were $0.82,0.81$ and 0.42 , respectively. The regional economy also influences the rural economy. With the progression of non-agricultural employment in rural areas, the increased proportion of wage- and salary-based income improves farmers' net income per capita, but the financial cost for farmers to travel to a city is generally higher. On the other hand, the sustained growth of income markedly progresses rural construction and extension of rural residential lands. Furthermore, rural residential lands are under the influence of geographical location: the closer to the metropolis and the better the transportation development, the nearer the rural residential lands are to market. With the stimuli of market demands, modern agriculture has the chance to develop in the metropolitan suburbs, and the power of rural economic growth is reinforced - distance to downtown and transportation P-values reached 0.66 and 0.72 , indicating that rural development in the metropolitan suburbs actually boosts construction of rural residential lands. Additionally, regional resources of agricultural lands, instead of economic interests from regional agricultural lands, affect land use in rural residential areas to a certain extent. The P-value of crop yield per unit area was 0.32. The higher the crop yield per unit area, the lower the agricultural comparative benefits, which usually occurs in traditional agricultural regions where the rural economy is always supported and dominated by migrant workers, with the proportion of agricultural income lower. The agricultural area per capita P-value was 0.42 , suggesting that human-land conflict in rural areas is pressing on livelihood transition. In less advanced mountainous regions, the tense relationship forces farmers to travel to cities to find work, reinforcing housing construction capacity in rural areas and causing the creation of new buildings despite old houses remaining. It is notable that agricultural production investment factors do have effects on changes of land use in rural areas, including total power of agricultural machinery $(\mathrm{P}=0.33)$ and irrigation rate $(0.21)$. Specifically, total power of agricultural machinery incorporates agricultural mechanization and modernization. 
Agricultural modernization improves agricultural efficiency and the higher the agricultural modernization, the smaller the negative effects from agricultural production systems, as a mechanized mode of agricultural production replaces manual labor, improving efficiency. Nonetheless, the issue of rural residential land is widespread and the role of agricultural modernization is not fully exploited in most rural areas, so that the area of rural residential sites continues to increase. During urbanization, the production systems are weakening, but residential sites in villages continue to improve because farmers lack a sense of belonging in both rural and urban areas.

\subsection{Analysis of influencing factors of spatial distribution of rural settlements}

Rural settlements and land use patterns are influenced by natural and human factors. The factors influencing rural settlements and land use can be ascertained using previous research and dialogue with locals. Distance of rural settlements to provincial capitals, prefecture-level cities and county-level cities should also be taken into account, because a central city has collective and divergent properties, affecting rural settlements and land use patterns (Table 2).

Table 2 Influencing factors on rural settlements and spatial distribution of land use

\begin{tabular}{lll}
\hline Natural conditions & Point (centrality) & Axis (traffic lines and rivers) \\
\hline Dem $\left(\mathrm{x}_{1}\right)$ & Distance to provincial capital $\left(\mathrm{x}_{5}\right)$ & Distance to railway $\left(\mathrm{x}_{11}\right)$ \\
Slope $\left(\mathrm{x}_{2}\right)$ & Distances to prefecture-level city $\left(\mathrm{x}_{6}\right)$ & Distance to expressway $\left(\mathrm{x}_{12}\right)$ \\
Temperature $\left(\mathrm{x}_{3}\right)$ & Distances to county-level city $\left(\mathrm{x}_{7}\right)$ & Distance to national road $\left(\mathrm{x}_{13}\right)$ \\
Precipitation $\left(\mathrm{x}_{4}\right)$ & Distance to counties $\left(\mathrm{x}_{8}\right)$ & Distance to provincial road $\left(\mathrm{x}_{14}\right)$ \\
& Distance to towns $\left(\mathrm{x}_{9}\right)$ & Distance to county or village roads $\left(\mathrm{x}_{15}\right)$ \\
& Distance to villages $\left(\mathrm{x}_{10}\right)$ & Distance to rivers $\left(\mathrm{x}_{16}\right)$ \\
\hline
\end{tabular}

Figure 6 shows results of raster image processing on the distribution of land use types as per distance allocation and binarization processing $(0,1)$, performed on rural residential sites in 2010 before logistic regression modeling on residential site distribution and influencing factors. As it is a departure from classical statistics to perform regression with all raster data, stratified sampling was used in the research. Since logistic regression of spatial distribution of rural residential sites diversifies in scales, in this study vector data of rural residential sites in 2010 were converted as per binarization processing $(0,1)$ and influencing factors were converted with scales at 100, 300, 600, 900, 1200, 1500, 1800, 2100, 2400 and $2700 \mathrm{~m}$. At the same time, logistic regressions were conducted of residential sites with influencing factors and ROC examination was performed between predicted probability and that measured in order to seek the optimal regression scale. It can be concluded that the raster scale at $300 \mathrm{~m}$ and examination value (ROC) at 0.832 presented the optimal simulation results.

On the basis of selection of influencing factors, logistic regression was then performed on probability with influencing factors on urban construction lands, and the logistic regression model was established, as follows:

$$
\begin{aligned}
\log \left(\frac{P}{1-P}\right)= & -0.005475 x_{1}-0.075388 x_{2}+0.000489 x_{3}-0.000030 x_{4} \\
& +0.000001 x_{5}-0.000009 x_{6}+0.000005 x_{7}+0.000001 x_{8} \\
& +0.000036 x_{9}+0.000064 x_{10}+0.000004 x_{11}-0.000026 x_{12} \\
& +0.000005 x_{13}-0.000033 x_{14}-0.000085 x_{15}+0.000048 x_{16}+2.131258
\end{aligned}
$$



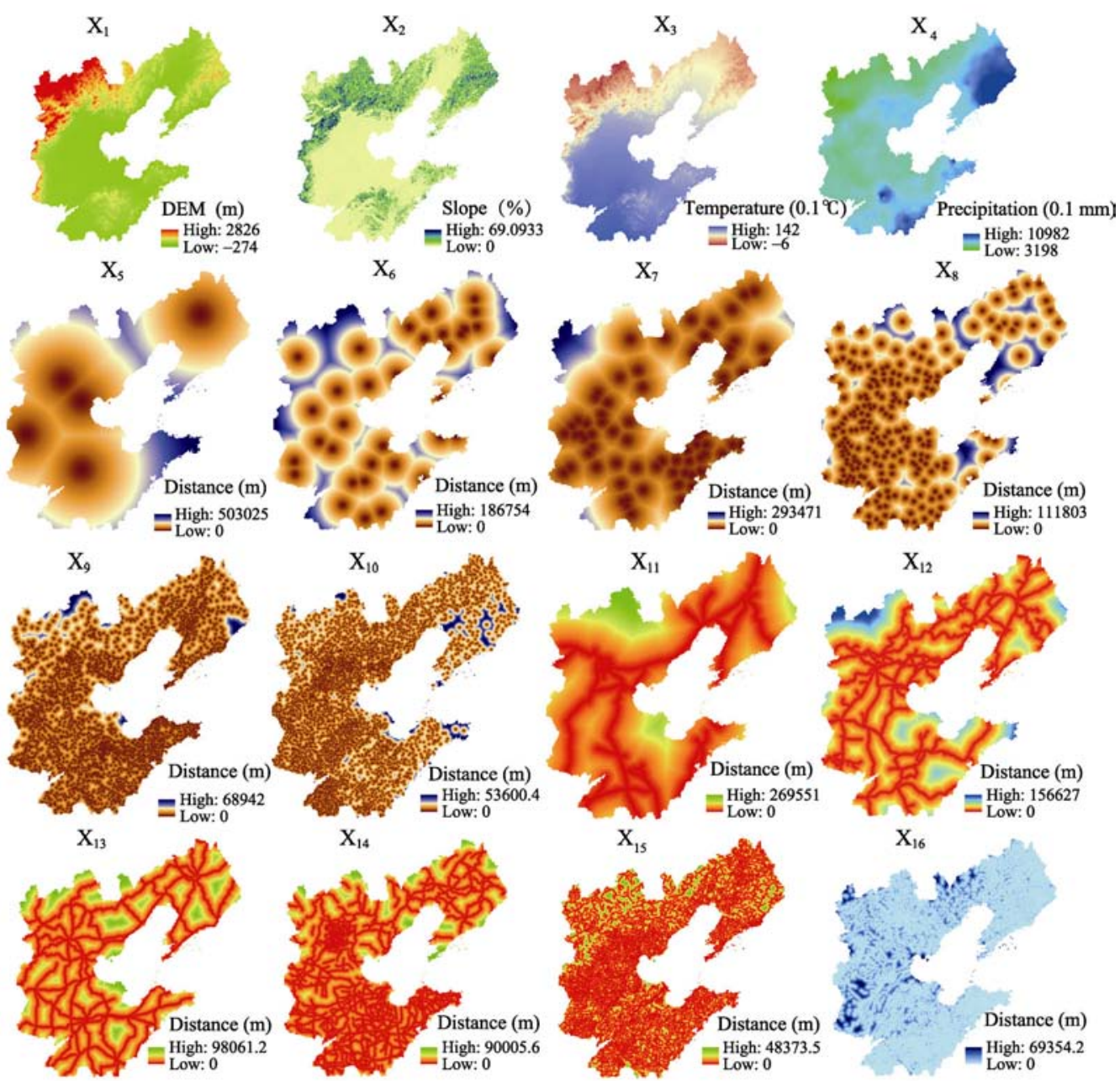

Figure 6 Factors influencing rural settlements and spatial distribution of land use

It is known that the formation, development and spatial distribution of rural settlements are a result of multiple factors, of which natural factors are fundamental and human/social factors are driving forces. Terrain, economy, and transportation are the dominant factors influencing the distribution pattern of rural settlements. Specifically, landform or terrain not only provides space for habitation and development, but also limits its extension. Flat areas are characterized by large-scale residential sites, whereas agricultural regions are generally extensive. With increasing altitude, in mountainous areas in particular, either production or the habitable environment is poor, directly resulting in scattered and small-scale residential sites. Transportation plays an essential role in rural settlement formation: changing traffic locations of a rural settlement and improvement of transportation infrastructure affects the spatial distribution of surrounding rural residential sites. For example, rural residential sites are densely concentrated near county or provincial roads, however the distribution in the vicinity of a traffic artery, such as expressways and railways, is limited in some aspects, as traffic accessibility and security is a consideration. The effects of central towns should never be ignored either. The centrality of villages or towns, for instance, considerably influences the 
spatial distribution of rural settlement land. Therefore, rural spatial pattern should be centered on villages or towns in order to build a well-organized system and provide basic public services for natural villages.

\section{Rural settlements and land use optimization strategies thinking}

\subsection{Construction of new pattern for villages or towns}

From the perspective of terrain system structure and function optimization, rural constructions on varied terrains should be improved in a methodical way, providing innovative systems and guaranteed farmers' legal rights. The construction of new patterns for villages or towns refers to spatial distribution, administrative divisions and management systems of counties, key towns, central towns and central villages, including space for human habitation, industry, ecology and culture. On the basis of the urban-rural terrain system and transition rules, it is recommended that: rural population clustering and equal exchange of urban-rural factors is promoted; rural spatial reconstruction is optimized; urban-rural resources are allocated in advance; territorial function and values in rural areas is evaluated; developmental and supporting potential is assessed in order to explore new coupling modes in terms of population, land, industry and ecological coordination; and enterprise innovation, farmer subjectivity and sequential order of rural spaces is stimulated. Strategically, it is important to: implement construction planning of new-type beautiful villages and towns in a systematic way; invigorate urbanization of nearby villages or towns; build spatial systems and comprehensive treatment systems to prevent some social traps; explore a long-term strategy for intensification integration and collective development of industries in rural areas; and to coordinate equal development chances for rural and urban areas. As for systems, governments should: deepen the urban-rural integration system; insist on urban-rural coordination and the principle of people first, in order to completely transform the concept of city, citizen or industry first; and create a new environment for new urbanization and urban-rural integration.

\subsection{Advancement of comprehensive and specific improvements of hollowing issues}

In regional areas, it is necessary to determine the development stage and type of hollowing issue, so that specific improvements can be made according to circumstances. For example, undeveloped hollowing villages should: reinforce the role of planning; boost improvements of organizations, industries and spaces, with central villages constructed; develop modernized agriculture, with increased intensive use of rural lands; rationally allocate public resources avoiding waste or overlapping investment; establish a healthy urbanization system of middle or small sized cities-central towns-central village (community)-grass-root villages.

In contrast, in developed rural areas: living, production and ecological spaces should be a priority in planning, to optimize village layout available, shaping central assemblages of population, industry and organizations; large-scale production, centralization of living space and ecologicalization of the environment should be promoted, aiming at coordinating and developing resources, environment, economy and society, transforming the hollowing village to a well-developed one by a series of improvements and urbanization. Finally, a new pattern would emerge, characterized by regional differences but a similarity in life quality and coordinated development between rural and urban areas. 
As for hollowing villages with moderate development, it is necessary to explore the approach that allows farmers to peacefully and contentedly live, work and be respected in cities. Specifically, it is recommended that land systems promote the transition from agricultural to non-agricultural status, and rural urbanization and economic or social sustainable development is investigated - particularly in agricultural regions on plains, central towns, villages with prominent hollowing issues, extensively idle lands, and intensive villages, or villages dominated by agriculture - with rural land improvement as a breakthrough and agricultural industrialization and modernization as impetus, in order to accomplish centralization of human habitation, organization of production and large-scale management of lands. In general, new-type urbanization lays the foundation for advancing comprehensive improvements on hollowing villages, an approach that should be supplemented by improving urbanization through optimization, reconstruction of specific rural organization, industry and space structure, in order to accelerate construction of new countryside and equitable development of urban and rural areas.

\section{Conclusions}

(1) The rural settlement distribution pattern in the Bohai Rim is remarkable in its spatial variation. The $5 \times 5 \mathrm{~km}$ grid cells that contain more than 5.0 rural-settlement sites are distributed in a six-area pattern in the Bohai Rim, and rural settlements in agricultural regions in south Hebei and southwest Shandong are highly dispersed, suggesting rural settlement density keeps increasing from northeast to southwest, characterized by high density and a dispersed spatial distribution in traditional agricultural regions. In Shandong, for instance, most rural settlements are scattered, and the number of rural settlements in most grid cell exceeds 10.0, indicating that the issue of scattering and hollowing is much more common in rural residential lands. On the plateau of Hebei and the Changbai Mountains, rural settlements are distributed dispersedly, with less than 5.0 rural settlements in each grid cell.

(2) Rural settlements show dramatic differences in terms of spatial distribution and dynamic degrees in the Bohai Rim. In distribution and scale, rural residential land is always extensive on plains, with a high density of rural settlements - the North China Plain in particular - and rural residential land in the south of Shandong also encompasses large areas, with most residential sites in the $5 \times 5 \mathrm{~km}$ grid cell exceeding $3 \mathrm{~km}^{2}$. However, traditional agricultural regions always become the regions with underdeveloped economies, industrialization and tertiary industries, characterized by low urbanization rates.

(3) The urban-rural transition has changed land use types in rural settlements' neighboring cities, as well as landscape patterns. The number of grid cells with residential sites exceeding $3 \mathrm{~km}^{2}$ increased from 3174 (14.58\%) in 1985 to 3702 (17.00\%) in 2010. Between 1985 and 2010, the proportion of grid cells with positive dynamic degrees in rural settlement areas was 57.38\%, mainly distributed across traditional agricultural regions in the Bohai Rim, with negative dynamic degrees accounting for $42.62 \%$ of the grid cells, in large- and medium-sized city suburbs. Urban space continues to expand, and residential sites in the rural-urban continuum of provincial capitals or prefecture-level cities are increasingly transformed into urban lands at rapid speed, with negative dynamic degree of land use in suburbs. In rural areas, landscape pattern has witnessed dramatic changes, and in traditional rural areas, residential sites are growing, which is more significant on the plains in terms of growth 
rate and scale.

(4) Rural settlements' spatial distribution demonstrated some geographically directional features, including the direction of: traffic, center, cultivated land resources and the livableness. Level of regional rural economic development and the degree of change in the non-agricultural labor force, farmers' income and other factors, have some influence on the dynamic changes of rural residential land areas. The natural environment, transportation, economic development and farmers' income all have effects on land use type and pattern of rural settlements. It is a core objective for future rural sustainable development to reconstruct rational spatial patterns of villages or towns and well-organized village-town systems, to build central villages, key towns or central towns, and to optimize or reconstruct production, living and eco-space of rural areas. Developing the rural spatial reconstruction theory is of significance for rural geographical research.

\section{References}

Bai X M, Shi P J, Liu Y S, 2014. Realizing China’s urban dream. Nature, 509: 158 - 160.

Giuseppina Siciliano, 2012. Urbanization strategies, rural development and land use changes in China: A multiple-level integrated assessment. Land Use Policy, 29(1): 165 - 178.

Guo L Y, Yang R, Wang D L, 2012. A study on the spatial difference of farmland nitrogen nutrient budget in the Bohai Rim region, China. Journal of Geographical Sciences, 22(4): 761-768.

Guo X D, Ma L B, Zhang Q Y, 2013. The spatial distribution characteristics and the basic types of rural settlement in loess hilly area: Taking Qin’an county of Gansu province as a case. Scientia Geographica Sinica, 33(1): 45-51. (in Chinese)

Han F, Cai J M, 2011. The evolution and reconstruction of peri-urban rural habitat in China. Geographical Research, 30(7): 1271-1284. (in Chinese)

He R W, Chen G J, Liu S Q et al., 2012. Research progress and tendency of Chinese rural settlements geography, Progress in Geography, 31(8): 1055-1062. (in Chinese)

Jin Q M, 1988. The history and current trend of research on rural settlement geography in China. Acta Geographica Sinica, 43(4): 311-317. (in Chinese)

Liu Y S, Liu Y, Cheng Y F, 2010. The process and driving forces of rural hollowing in China under rapid urbanization. Journal of Geographical Sciences, 20(6): 876-888.

Liu Y S, Liu Y, Zhai R X, 2009. Geographical research and optimizing practice of rural hollowing in China. Acta Geographica Sinica, 64(10): 1193-1202. (in Chinese)

Liu Y S, Yang R, 2012. The spatial characteristics and formation mechanism of the county urbanization in China. Acta Geographica Sinica, 67(8): 1141-1150. (in Chinese)

Liu Y S, Lu S S, Chen Y F, 2013a. Spatio-temporal change of urban-rural equalized development patterns in China and its driving factors. Journal of Rural Studies, 32: 320-330.

Liu Y S, Yang R, Li Y H, 2013b. Potential of land consolidation of hollowed villages under different urbanization scenarios in China. Journal of Geographical Sciences, 23(3): 503-512.

Liu Y S, Yang R, Long H L et al., 2014. Implications of land-use change in rural China: A case study of Yucheng, Shandong province. Land Use Policy, 40: 111-118.

Long H L, 2014. Land consolidation: An indispensable way of spatial restructuring in rural China. Journal of Geographical Sciences, 24(2): 211-225.

Long H L, Li Y R, Liu Y S et al., 2012. Accelerated restructuring in rural China fueled by 'increasing vs. decreasing balance' land-use policy for dealing with hollowed villages. Land Use Policy, 29: 11-22.

Long H L, Liu Y S, Li X B et al., 2010. Building new countryside in China: A geographical perspective. Land Use Policy, 27(2): 457-470. 
Long H L, Liu Y S, Wu X Q et al., 2009. Spatio-temporal dynamic patterns of farmland and rural settlements in Su-Xi-Chang region: Implications for building a new countryside in coastal China. Land Use Policy, 26(2): 322-333.

Mathera A S, Hillb G, Nijnik M, 2006. Post-productivism and rural land use: Challenge for theorization. Journal of Rural Studies, 22(4): 441-455.

Shan Y B, Ma X D, Qiu F D, 2012. Distribution patterns characteristics and type classification of the rural settlements in central Jiangsu province. Scientia Geographica Sinica, 32(11): 1340-1347. (in Chinese)

Tian G J, Qiao Z, Zhang Y Q, 2012. The investigation of relationship between rural settlement density, size, spatial distribution and its geophysical parameters of China using Landsat TM images. Ecological Modelling, 231(24): 25-36.

Woods M, 2005. Rural Geography: Processes, Responses and Experiences in Rural Restructuring. London: Sage, 3-26.

Woods M, 2007. Engaging the global countryside: Globalization, hybridity and the reconstitution of rural place. Progress in Human Geography, 31(4): 485-507.

Wang J F, Li X H, Christakos G et al., 2010. Geographical detectors-based health risk assessment and its application in the neural tube defects study of the Heshun Region, China. International Journal of Geographical Information Science, 24(1): 107-127.

Xi J C, Zhao M F, Ge G S, 2011. The micro-scale analysis of rural settlement land use pattern: A case study of Gouge village of Yesanpo scenic area in Hebei province. Acta Geographica Sinica, 66(12): 1707-1717. (in Chinese)

Yang R, Liu Y S, Chen Y F, 2012. Comprehensive measure and partition of rural hollowing in China. Geographical Research, 31(10): 1876-1882. (in Chinese)

Yang R, Liu Y S, Chen Y F et al., 2013. The remote sensing inversion for spatial and temporal changes of multiple cropping index and detection for influencing factors in the Bohai Rim in China. Scientia Geographica Sinica, 33 (5): 521-527. (in Chinese)

Yin H T, Chen Z X, 1995. Spatial distribution and evolution of the rural settlements in Shaanxi province. Human Geography, 10(4): 17-24. (in Chinese)

Zhou G H, He Y H, Tang C L et al., 2013. Dynamic mechanism and present situation of rural settlement evolution in China. Journal of Geographical Sciences, 23(3): 513-524. 